\title{
CALENDAR AGE OF LISAKOVSKY TIMBERS ATTRIBUTED TO ANDRONOVO COMMUNITY OF BRONZE AGE IN EURASIA
}

\author{
Irina P Panyushkina ${ }^{1} \bullet$ Barbara J Mills $^{2} \cdot$ Emma R Usmanova $^{3} \bullet$ Li Cheng $^{4}$ \\ ABSTRACT. We measured radiocarbon ages of 22 decadal replications and 1 bulk group from 5 tree-ring specimens using \\ acid-base-acid pretreatment and accelerator mass spectrometry (AMS). The study has the goal of refining the precision and \\ resolution of a segment of the conventional Bronze Age chronology in the Eurasian steppe attributed to the multicultural com- \\ munity known as Andronovo. The archaeological timbers were gathered from 3 cemeteries at the Lisakovsky cluster of sites \\ in Kazakhstan, where there is a prominent Andronovo occurrence that appears to show evidence of overlapping Alakul and \\ Fedorovo cultures in the southern margin of the Eurasian steppe. The new set of Andronovo calendar dates derived from ${ }^{14} \mathrm{C}$ \\ wiggles and a composite floating tree-ring chronology places the cultural overlap from 1780 to $1660 \mathrm{cal} \mathrm{BC}$. Results indicate \\ older ages of artifacts from the Lisakovsky site than were previously determined by the typological chronology, shifting them \\ from the Late Bronze Age to also include the transition between the Middle and Late Bronze Age. The chronological order \\ of the Lisakovsky cemeteries provides strong evidence of contemporaneity of the Alakul and Fedorovo cultures in the Tobol \\ River Valley for a portion of the 120-yr period of occupation. We discuss an application of the dated Alakul-Fedorovo overlap \\ to the relationship and origin of different groups of the Andronovo community in the Ural region. Our results demonstrate the \\ substantial power that tree rings from Bronze Age timbers provide for developing a precise and highly resolved calendar chro- \\ nology of prehistoric human occupation in the Eurasian steppe during the 2nd millennium BC.
}

\section{INTRODUCTION}

The Middle and Late Bronze Age (MBA and LBA, respectively) of the Eurasian steppe includes remarkable diversity in settlements, burial practices, and material cultures. The transition between the MBA and LBA (between 1700 and $1500 \mathrm{BC}$ ) is characterized by the rapid expansion of dispersed settlements over a large territory (from the Don River to the Yenisey River) and an apparent decrease in social complexity (Kuzmina 1994). This diversity has traditionally been associated with distinctive local traditions (or cultures), such as the Andronovo cultural community (Koryakova and Epimakhov 2007). A central issue is whether each of these dozen variants of diverse traditions represents different ethnic groups or cultures resulting from migration or from other forms of interaction between groups (Grigoriev 2002; Anthony 2007).

The current scheme of the Bronze Age radiocarbon chronology in the Eurasian steppe has documented comparative dates for an extended number of sites located in the Volga region, the Urals, and Siberia (Gorsdorf et al. 2004; Hanks et al. 2007; Shishlina et al. 2007). The ${ }^{14} \mathrm{C}$ sequence corresponds to the period 2800-800 BC, which is associated with the main conventional phases of the Bronze Age: Early, Middle, Late, and Final. Each period lasts for about 200-400 yr, but shorter phases within the periods have not been defined because of the coarse resolution of the chronology. Chronological arrangement of the cultural variants in the Eurasian steppe could not be determined with the current version of this chronology for many reasons, including 1) the scarcity of ${ }^{14} \mathrm{C}$ dates from multiphased archaeological sites associated with more than 1 cultural tradition, and 2) errors and interpretation uncertainties resulting from comparing radiometric measurements over the last few decades derived from different conditions and materials (human bones, animal bones, fish bones, fabric, wood) (Scott et al. 2007; Shishlina et al. 2007).

\footnotetext{
${ }^{1}$ Laboratory of Tree-Ring Research, University of Arizona, Tucson, Arizona 85721, USA. Corresponding author. Email: panush@ltrr.arizona.edu.

${ }^{2}$ Anthropology Department, University of Arizona, Tucson, Arizona 85721, USA.

${ }^{3}$ Karaganda State University, Karaganda 100028, Kazakhstan.

${ }^{4}$ Department of Physics, University of Arizona, Tucson, Arizona 85721, USA.
} 
Another shortcoming of the current ${ }^{14} \mathrm{C}$ chronology is that the ${ }^{14} \mathrm{C}$ dates do not provide sufficiently high resolution to assign calendar dates to particular ceramic designs of the Andronovo community (Frachetti 2004). Variations in pottery techniques, styles, and decorative patterns are the main basis for formal descriptions of archaeological cultures and their variants (Potemkina 1985). Although the formal attribution of archaeological variants of the Andronovo cultural family derived from ceramic patterns and burial rites is highly subjective and causes ambiguous interpretations, a collective call for refinement of the current inadequate resolution of the Bronze Age ${ }^{14} \mathrm{C}$ chronology has emerged (Hanks et al. 2007). A calendar chronology that would demonstrate whether the different variants are contemporaneous, overlapping in part, or sequential could be developed with a highly resolved ${ }^{14} \mathrm{C}$ chronology composed of precise and accurately calibrated ${ }^{14} \mathrm{C}$ measurements.

From our point of view, ${ }^{14} \mathrm{C}$ dating of Andronovo archaeological timbers should play a key role in the chronology refinement. Discoveries of timbers from Bronze Age archaeological sites across the Eurasian steppe have been frequently reported (Gening et al. 1992; Usmanova 2005; Stefanov and Korochkova 2006). Timbers were routinely and widely used in both settlement and burial constructions. Wood crafts have even contributed to the diagnosis of cultural identity and site stratigraphy (Potemkina 1985). We surveyed collections from museums and archaeological laboratories in the Urals region to identify wood that is available and suitable for tree-ring analysis. Lack of awareness by local archaeologists about the potential of tree rings for ${ }^{14} \mathrm{C}$ dating has resulted in great scarcity of wood material surviving through decades of intensive excavation programs of the Andronovo occurrences. Nevertheless, a number of sites in the Urals and the Don River (west of the Ural River) associated with the Alakul and Fedorovo cultures as well as the Abashevo, Sintashta, Petrovka, and their variants, fortunately have archaeological timber remains with a degree of wood preservation suitable for tree-ring dating analysis.

Here, we present ${ }^{14} \mathrm{C}$ measurements from crossdated tree rings sampled at the Lisakovsky archaeological site dated by ceramic topology to the Late Bronze around 1500 and $1400 \mathrm{BC}$. The site exhibits archaeological occupations related to the Fedorovo, Alakul, and a mixed variant of FedorovoAlakul cultures (Usmanova 2005). The main goals of this study are to 1) determine precise calendar ages of cemeteries at the Lisakovsky burial site, and 2) achieve a desirable resolution of the ${ }^{14} \mathrm{C}$ chronology necessary to establish duration of the Fedorovo and Alakul traditions within the southern border of the Andonovo distribution in the Urals.

\section{Archaeological Context}

The Ural Mountains region lies in the middle of this enormous Andronovo cultural province and is considered to be the core of this prehistoric population. The great diversity in cultural development throughout the southern Urals (Russia and Kazakhstan) is associated with direct interaction of 2 major styles of ceramics and distinctive burial programs, Alakul and Fedorovo, which shaped the entire Andronovo community during the transition (Koryakova and Epimakhov 2007). These have been interpreted as different "cultures" within the Russian tradition of archaeology. The conventional chronology of the Bronze Age dates the Andronovo, including the Alakul and Fedorovo cultures, in the steppes of the southern Urals between 1500 and 1100 BC (LBA). Many archaeological materials suggest apparent co-existence of a variety of cultural traditions through the MBA and LBA across this region (Grigoriev 2002), although their calendar dates might be sparse in comparison with the number of excavated sites, and their large error bars span the entire conventional phases of the Bronze Age.

The Alakul and Fedorovo subterranean settlements had a simple linear plan occupying a small area usually located along the first terrace above the river (Potemkina 1985). Their cemeteries were sit- 
uated in close proximity to the river banks and had more numerous burials than the earlier settlements (up to 150 burials). The Fedorovo sites were much smaller in size but were occupied similarly to the Alakul locations or the same sites in the lower parts of river or lake valleys. The Fedorovo occurrences have been documented mainly in the northern Kazakhstan area of the southern Urals (Kuzmina 1994). In contrast, the Alakul sites are distributed within a much larger territory and found even in the Don River basin (Stefanov and Korochkova 2006). The cultural marker of the Alakul funeral tradition is that the inhumation graves are walled and roofed with timbers, whereas the Fedorovo people built enclosures outside of cremation graves and around the cemetery from stones or wooden poles. Stone, rather than wood, was more often used in grave construction attributed to Fedorovo people but not exclusively. The Fedorovo tradition of body cremation produced remains of firewood, burned pit walls, piles of charcoal, and unburned small branches (Usmanova 2005).

The Alakul and Fedorovo mixed variant has been observed in multilayered stratigraphy of settlements and their related cemeteries. There are just a few well-studied sites documenting the presence of Fedorovo and Alakul assemblages as well as their mixed variant Alakul-Fedorovo at a single location (Usmanova 2005; Stefanov and Korochkova 2006). Although the evidence supports coexistence of these 2 traditions in the southern Urals (Koryakova and Epimakhov 2007), debates on the origins of these 2 cultures and migration remain (Anthony 2007), mainly because the chronological order of these assemblages has not been established. The incidence of timbers in both the Alakul and Fedorovo burials suggests an opportunity to employ tree rings in high-resolution ${ }^{14} \mathrm{C}$ dating of these assemblages.

\section{MATERIALS AND METHODS}

\section{Archaeological Site}

We selected a multiphase Andronovo cluster of sites named Lisakovsky 1-6 in northern Kazakhstan, which has been extensively excavated, with unearthed timbers preserved at a local museum. The Lisakovsky archaeological complex is located in the steppe landscape of the upper Tobol River valley in the Kostanay oblast region $\left(52^{\circ} 32^{\prime} 13^{\prime \prime} \mathrm{N}, 62^{\circ} 29^{\prime} 37^{\prime \prime} \mathrm{E}\right)$. The site includes 6 cemeteries (numbered 1-6) and 1 settlement. All cemeteries are aligned along a 12-km line about $3 \mathrm{~km}$ apart from each other within the Tobol River floodplain.

The burials are attributed to the Alakul, Fedorovo, and mixed variants (Usmanova 2005). Generally, a cemetery plan includes a cluster of kurgans (2-4) bordered with a stone enclosure and an individual ditch or a group of ditches. Kurgans could have 1 or several pit graves in the center. The kurgans are surrounded by a few dozen smaller features that have graves and stone enclosures. Stone slabs and other earth structures were identified on the ground, which probably served as gathering spots during ritual offerings. Approximately $85-90 \%$ of the Lisakovsky site was excavated according to field reports archived at the Museum of History and Culture of the Upper Tobol region. The archaeological data from the Lisakovsky complex have been partially analyzed. A formal description of artifacts and rites was done for only 1 cemetery, Lisakovsky 1 , which was almost fully excavated and is consequently the most studied cemetery within the Lisakovsky complex (Usmanova 2005).

Evaluation of the Lisakovsky data and its contribution to regional studies of the Bronze Age in Eurasia has just begun. The archaeological materials from this complex have made their way to recent studies on animal domestication and dietary patterns in the prehistoric Eurasian steppe as well as the history of Eurasian metal-working art and textiles (Koryakova and Emimakhov 2007). Apparently, Lisakovsky has the potential to become a key site for the Fedorovo and Alakul cultures in the southern Ural steppes, representing the Andronovo community in the south. 


\section{Archaeological Timbers}

The timbers excavated at the Lisakovsky cemeteries have been stored at the Museum of History and Culture of Upper Tobol (Lisakovsk City) for a decade. To our knowledge, it happens to be the largest wood collection associated with the Andronovo cultures. Timbers preserved in kurgans of the Alakul culture and grave pits of the mixed Alakul-Fedorovo variant mostly came from 3 cemeteries: Lisakovsky 1, 4, and 5. The Lisakovsky 1 cemetery is the largest burial field, organized into 4 burial groups that includes 174 burials and 75 ritual structures almost completely excavated (Usmanova 2005). There are 77 burials associated with the Alakul and 97 burials with the Fedorovo culture. Twenty-three burials have been identified as mixed variants of these cultures. The cemeteries at Lisakovsky 4 and 5 are much smaller and have been critically damaged by recent farming. Cemetery 4 is composed of 18 burials and 12 stone enclosures mainly attributed to the Alakul culture. Only 2 burials trace the Fedorovo ceramics. Cemetery 5 has only 3 burials and 2 enclosures identified solely as Alakul structures.

A total of 11 wood specimens were found reasonably preserved and of sufficient size for a tree-ring study. Table 1 shows the wood specimens obtained from each cemetery. Specimens from Lisakovsky 1 and 5 were excavated from single kurgans. The timbers from Lisakovsky 4 were conserved in 2 kurgans, a pit grave, and an enclosure located apart from each other. The timbers were part of burial structures such as floor planks, beams, overhead cover poles, and plank wall retainers. We found descriptions of a much larger number of timbers excavated from the cemeteries in unpublished field reports, but the samples were not collected or did not survive. The length of preserved wood fragments ranges from 3 to $50 \mathrm{~cm}$ and the diameters range from 3 to $35 \mathrm{~cm}$. Wood anatomy analysis of timbers from the Lisakovsky site indicates that tree-ring samples were mainly cut from Pinus sylvestris L. (Scots pine) trees. Birch wood (Betula pendula) occurs sporadically among the studied archaeological timbers. This study uses only Scots pine wood for dating.

Table 1 Tree-ring specimens from archaeological timbers excavated from the Lisakovsky complex.

\begin{tabular}{|c|c|c|c|c|c|c|}
\hline $\begin{array}{l}\text { Sample \& } \\
\text { cemetery } \\
\text { nr. (L) }\end{array}$ & $\begin{array}{l}\text { Burial feature/ } \\
\text { wood source }\end{array}$ & $\begin{array}{l}\text { \# of wood } \\
\text { pieces/\# of } \\
\text { tree-ring } \\
\text { samples }\end{array}$ & Wood ID & $\begin{array}{l}\text { Pith/ } \\
\text { outer } \\
\text { rings }\end{array}$ & $\begin{array}{l}\text { Length of } \\
\text { tree-ring } \\
\text { width } \\
\text { series }\end{array}$ & $\begin{array}{l}\text { Estimated total } \\
\text { \# of tree rings/ } \\
\text { \# missing outer- } \\
\text { most rings }\end{array}$ \\
\hline L1-k3 & $\begin{array}{l}\text { Kurgan 3/wall } \\
\text { beam, column }\end{array}$ & $2 / 8$ & Pinus sylvestris L. & $\mathrm{Y} / \mathrm{N}$ & 43 & $60 / 20$ \\
\hline L4-k1 & Kurgan 1/floor & $1 / 5$ & P. sylvestris $\mathrm{L}$. & $\mathrm{N} / \mathrm{N}$ & 53 & $80 / 30$ \\
\hline L4-k6 & $\begin{array}{l}\text { Kurgan 6/floor, } \\
\text { overhead cover }\end{array}$ & $4 / 22$ & P. sylvestris $\mathrm{L}$. & $\mathrm{Y} / \mathrm{Y}$ & 154 & $160 / 5$ \\
\hline L4-sr9 & Enclosure 9/pole & $1 / 1$ & P. sylvestris L. & $\mathrm{N} / \mathrm{N}$ & 6 & $20 / 10$ \\
\hline L5-k1 & Kurgan 1/wall & $2 / 2$ & P. sylvestris $\mathrm{L}$. & $\mathrm{N} / \mathrm{N}$ & 20 & $25 / 5$ \\
\hline
\end{tabular}

\section{Tree Rings}

Tree rings were used in this study in 2 ways: 1) crossdating tree-ring width series within a kurgan, a cemetery, and between cemeteries; and 2) sequencing tree-ring groups for ${ }^{14} \mathrm{C}$ wiggles. The wood specimens were examined through multiple sampling of tree rings from the same timber, because most large fragments were riddled with cracks and sometimes had displaced or broken-off pieces. To enhance clarity of ring boundaries, wood surfaces were shaved with a razor blade and tree rings were immediately analyzed on the fresh cuts. Tree-ring widths were measured in multiple samples using a Linux measurement system $(0.01 \mathrm{~mm}$ precision) where possible. We painstakingly obtained 
1 averaged tree-ring width series for the cemetery at Lisakovsky 1 and 2 others for Lisakovsky 4 (Figure 1, Table 1). Individual ages of trees used in the burial constructions varied from 12 to $160 \mathrm{yr}$ based on preserved pith/outer rings and field observations of wood diameter. Our best specimens produced tree-ring width series 43 to $154 \mathrm{yr}$ long. The mean widths of studied tree rings suggest that the timbers were taken from relatively young and fast-growing trees.
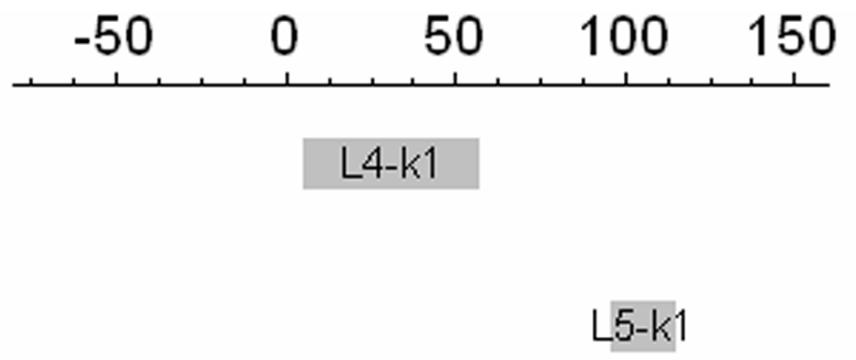

\section{L4-srg}

L1-K3

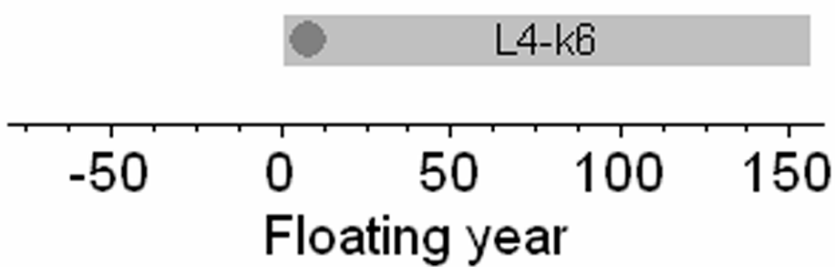

Figure 1 Floating composite tree-ring width chronology of the Lisakovsky site. Gray bars show length and position of individual tree-ring chronologies overlapped by means of tree-ring crossdating and ${ }^{14} \mathrm{C}$ dating. Dark gray circles mark tree-ring series with pith.

Crossdating was applied to the tree-ring width sequences to build a mean tree-ring width series from multiple measurements and to match the series using TSAP software (Rinn 2003), followed by verification of tree-ring overlaps with correlation statistics. Overlapping tree-ring series with close ${ }^{14} \mathrm{C}$ ages were also tested among different burial features and cemeteries. Within Lisakovsky 4 , we developed a composite chronology of tree-ring widths in addition to a floating tree-ring series for the cemetery at Lisakovsky 1 (Figure 1). Fortunately, we observed distinctive tree-ring patterns and a few pointer years of extreme low growth that aided development of a relatively short tree-ring series and allowed us to successfully overlap the series. All overlapped tree-ring series showed significant correlation statistics, with $t$ values above 3 . The variability of tree-ring width series (mean sensitivity 0.28 ) is high enough to establish reasonable crossdates from this material despite low numbers of samples and their imperfections. As will be discussed later, even this restricted number of crossdated series may contribute valuable details toward estimating the duration of cemetery development. 


\section{${ }^{14} \mathrm{C}$ Measurements}

The crossdated tree rings were subsampled into successive 10 -yr groups to process for ${ }^{14} \mathrm{C}$ measurements. Bulk rings were also taken in 1 case because the total number of rings was $<10$ (see Table 1). The subsampled rings were ground to 20-mesh powder and pouched into small filtering bags in 20to $30-\mathrm{mg}$ batches. We estimate $20 \mathrm{mg}$ of powdered wood is optimal for the ${ }^{14} \mathrm{C}$ measurements of a 10-ring group. Heavy contamination of wood samples with recent organic material such as grass roots, insect influx, etc. requires sampling wood 2-3 times the optimal amount so sufficient wood would remain after removing contaminants. We would recommend collecting at least $240 \mathrm{mg}$ per piece of archaeological wood containing about 40 rings.

We initially delignified our samples in an acetic acid-acidified bleaching solution (Sternberg 1989) to separate the $\alpha$-cellulose fraction of the wood. To our surprise, no cellulose was extracted from any samples, possibly because of their advanced state of decomposition. A similar result was realized during bleaching of archaeological larch wood from low-elevation grassland in the Altai Mountains (Panyushkina et al. 2007). We therefore suggest avoiding this method for pretreatment of tree rings from Bronze Age timbers collected in low-elevation, dry landscapes of Eurasia.

Ultimately, we employed acid-base-acid pretreatment on the wood samples to remove mobile carbonaceous material and soluble fulvic and humic acids (Lange et al. 2001). About $20 \mathrm{mg}$ of wood sample was placed into a test tube and $20 \mathrm{~mL}$ of $0.1 \mathrm{M} \mathrm{HCl}$ was added to remove mobile carbonaceous material. The test tube was then placed in a heating block at $70{ }^{\circ} \mathrm{C}$ overnight. After acidification, the sample was rinsed with deionized (DI) water until the $\mathrm{pH}$ was neutral. After decanting the last rinse water, $20 \mathrm{~mL}$ of $0.1 \mathrm{M} \mathrm{NaOH}$ was added into the tube and left in the heating block at $70{ }^{\circ} \mathrm{C}$ overnight to solubilize humic and fulvic acids. The solution was decanted and the sample was rinsed at last 3 times with DI water, then put into the heating block between rinses for 5 min for convective mixing of the solution. To insure that the sample was not basic and had no newly formed carbonates during base treatment, $20 \mathrm{~mL}$ of $0.05 \mathrm{~N} \mathrm{HCl}$ was added to the sample again and left in the heating block at $70{ }^{\circ} \mathrm{C}$ for $2 \mathrm{hr}$. Finally, the sample was rinsed with DI water and decanted until the $\mathrm{pH}$ of the last decanted solution was neutral.

The pretreated wood sample was placed into a vacuum oven at $60^{\circ} \mathrm{C}$ for $48 \mathrm{hr}$ to dry. Next, $4-6 \mathrm{mg}$ of the dried wood sample was combusted at $800{ }^{\circ} \mathrm{C}$ on a vacuum line in the presence of $\mathrm{CuO}$, after which the purified $\mathrm{CO}_{2}$ was collected. Graphite targets were prepared from the $\mathrm{CO}_{2}$ and then measured at the AMS Facility of the University of Arizona. ${ }^{14} \mathrm{C}$ ages (BP) were converted to calibrated ages (cal BP relative to AD 1950) using the CALIB 5.0.1 program (Stuiver et al. 2005). ${ }^{14} \mathrm{C}$ wiggles were matched visually with the 10-yr point spaced calibration curve (CalPal2007_Hulu; see http:// www.calpal.de/calpal/manual) by plotting against each other. Further, a Monte Carlo simulation tested a fit employing the GaussWM program (see Weninger 1997; Bronk Ramsey et al. 2001).

\section{RESULTS AND DISCUSSION}

\section{Radiocarbon Dates of Lisakovsky Timbers}

This study is the first ${ }^{14} \mathrm{C}$ dating of archaeological material from the Lisakovsky complex of sites. We measured ${ }^{14} \mathrm{C}$ ages of 22 decadal subdivisions from 4 tree-ring specimens and 1 bulk tree-ring sample from another specimen. The measurements resulted in $4{ }^{14} \mathrm{C}$ sequences, the longest of which had 11 points (Table 2). There is a consistency in variations of $\delta^{13} \mathrm{C}$ values within specimens (about $0.5 \%$ to $2.6 \%$ per specimen) as expected. Our cautious wood-handling measures-taken to avoid possible wood contamination from insecure storage of timbers at the museum collection for nearly 
a decade-were successful. Most ${ }^{14} \mathrm{C}$ dates fell between 1880 and $1660 \mathrm{cal} \mathrm{BC}$, although ${ }^{14} \mathrm{C}$ dates of the L1-k3 specimen appear to be older: 2050 and 1700 cal BC (Table 2). Dates from 3 specimens of Lisakovsky 4 and 1 specimen of Lisakovsky 5 clustered into a 270 -yr period. The ${ }^{14} \mathrm{C}$ ages of the Lisakovsky 1 (L1) specimen are scattered across a 250-yr period and happen to have the oldest dates. These dates suggest that the beginning use of L1 is older than previously known. Although ceramics dated the Lisakovsky site between 1500 and $1400 \mathrm{BC}$, the ${ }^{14} \mathrm{C}$ dates push its age toward the last half of the 2nd millennium BC.

Table $2{ }^{14} \mathrm{C}$ measurements of 10 -yr tree-ring groups (* marks 5- and 6-yr groups) obtained for archaeological Pinus sylvestris L. timbers at the Lisakovsky site.

\begin{tabular}{|c|c|c|c|c|c|c|c|}
\hline $\begin{array}{l}\text { Tree-ring } \\
\text { sample ID }\end{array}$ & $\begin{array}{l}{ }^{14} \mathrm{C} \text { sub- } \\
\text { sample ID }\end{array}$ & $\begin{array}{l}\text { Lab \# } \\
\text { (AA-) }\end{array}$ & $\begin{array}{l}\text { Ring \# } \\
\text { within } \\
\text { tree-ring } \\
\text { series }\end{array}$ & $\begin{array}{l}\delta^{13} \mathrm{C} \\
(\% \circ)\end{array}$ & $\begin{array}{l}{ }^{14} \mathrm{C} \\
(\mathrm{pMC})\end{array}$ & $\begin{array}{l}{ }^{14} \mathrm{C} \text { age } \\
\pm 1 \sigma \\
\text { (BP) }\end{array}$ & $\begin{array}{l}\text { Calibrated } \\
\text { date }(1 \sigma) \\
\text { cal BC }\end{array}$ \\
\hline \multirow[t]{4}{*}{ L1-k3 } & L1-K3-W1 & 78366 & $1-10$ & -25.5 & $0.63 \pm 0.003$ & $3659 \pm 40$ & 2050-1970 \\
\hline & L1-K3-W2 & 78367 & $11-20$ & -24.9 & $0.65 \pm 0.003$ & $3400 \pm 40$ & $1740-1660$ \\
\hline & L1-K3-W3 & 78368 & $21-30$ & -24.6 & $0.65 \pm 0.003$ & $3514 \pm 40$ & $1850-1770$ \\
\hline & L1-K3-W4 & 78369 & $35-39 *$ & -25.1 & $0.65 \pm 0.003$ & $3409 \pm 40$ & $1750-1660$ \\
\hline \multirow[t]{5}{*}{ L4-k1 } & L4-K1-W1 & 78374 & $1-10$ & -25.4 & $0.65 \pm 0.003$ & $3478 \pm 40$ & $1880-1790$ \\
\hline & L4-K1-W2 & 78375 & $11-20$ & -25.4 & $0.65 \pm 0.003$ & $3428 \pm 40$ & $1780-1680$ \\
\hline & L4-K1-W3 & 78376 & $21-30$ & -28 & $0.65 \pm 0.003$ & $3420 \pm 40$ & $1770-1670$ \\
\hline & L4-K1-W4 & 78377 & $31-40$ & -26.6 & $0.65 \pm 0.003$ & $3463 \pm 40$ & $1880-1740$ \\
\hline & L4-K1-W5 & 78378 & $41-50$ & -27 & $0.65 \pm 0.003$ & $3434 \pm 40$ & $1780-1690$ \\
\hline \multirow[t]{11}{*}{ L4-k6 } & L4-K6-W1 & 78379 & $1-10$ & -25.3 & $0.65 \pm 0.003$ & $3477 \pm 40$ & $1880-1790$ \\
\hline & L4-K6-W2 & 78380 & $12-21$ & -25.9 & $0.65 \pm 0.003$ & $3456 \pm 40$ & $1780-1740$ \\
\hline & L4-K6-W3 & 78381 & $22-31$ & -25.6 & $0.65 \pm 0.003$ & $3426 \pm 40$ & $1770-1680$ \\
\hline & L4-K6-W4 & 78382 & $32-41$ & -25.6 & $0.65 \pm 0.003$ & $3418 \pm 40$ & $1770-1660$ \\
\hline & L4-K6-W5 & 78383 & $31-40$ & -24.6 & $0.66 \pm 0.003$ & $3356 \pm 40$ & $1690-1610$ \\
\hline & L4-K6-W6 & 78384 & $6-15$ & -23.9 & $0.65 \pm 0.003$ & $3444 \pm 40$ & $1780-1690$ \\
\hline & L4-K6-W7 & 78385 & $16-25$ & -24.8 & $0.65 \pm 0.003$ & $3469 \pm 40$ & $1880-1740$ \\
\hline & L4-K6-W8 & 78386 & $26-35$ & -24.5 & $0.65 \pm 0.003$ & $3434 \pm 40$ & 1780-1690 \\
\hline & L4-K6-W9 & 78387 & 39-48 & -24.2 & $0.65 \pm 0.003$ & $3407 \pm 40$ & $1750-1660$ \\
\hline & L4-K6-W10 & 78388 & $49-58$ & -25.1 & $0.66 \pm 0.003$ & $3395 \pm 40$ & $1740-1660$ \\
\hline & L4-K6-W11 & 78389 & $59-68$ & -24.8 & $0.65 \pm 0.003$ & $3414 \pm 40$ & 1760-1660 \\
\hline \multirow[t]{2}{*}{ L4-sr9 } & L4-9 & 78392 & $1-6^{*}$ & -25.1 & $0.65 \pm 0.004$ & $3457 \pm 40$ & $1780-1740$ \\
\hline & & & & & & & $1880-1840$ \\
\hline \multirow[t]{2}{*}{ L5-k1 } & L5-K1-P1 & 78390 & $1-10$ & -24.3 & $0.65 \pm 0.003$ & $3422 \pm 40$ & $1770-1670$ \\
\hline & L5-K1-P2 & 78391 & $11-20$ & -24.8 & $0.65 \pm 0.003$ & $3437 \pm 40$ & $1780-1690$ \\
\hline
\end{tabular}

Replicated measurements were prompted to further increase precision of the calibrated ages. The decadal ${ }^{14} \mathrm{C}$ measurements were averaged per specimen (Table 2) to reduce possible stochastic errors in the calibration of ${ }^{14} \mathrm{C}$ ages. Use of the averaged ages of the decadal replications produces shorter 40- and 90-yr calendar dates per specimen. The averaged ${ }^{14} \mathrm{C}$ age of the Lisakovsky 1 sequence was fitted to the period 1860-1770 cal BC, Lisakovsky 4 to the middle of 18 th century BC, and Lisakovsky 5 to the period 1770-1680 cal BC. Averaging of decadal measurements derived under similar conditions and material reduced the age uncertainty by a few decades. ${ }^{14} \mathrm{C}$ ages derived from a single decade of sample L4-sr9 range between 1780 and 1740 cal BC at $68 \%$ probability, which is similar to the age of other specimens from this cemetery. This shows that averaging of replicated ${ }^{14} \mathrm{C}$ measurements might be useful to define the precision of calibrated ages for wood 
samples that have indistinct tree-ring boundaries and/or when reconstruction of a tree-ring sequence is impossible because specimens have crumbled to a jumble of pieces.

The decadal ${ }^{14} \mathrm{C}$ measurements contributed to 4 wiggle chronologies, providing an opportunity for highly resolved calibration of ${ }^{14} \mathrm{C}$ ages. We found the best relationship between ages through visual matching rather than with Monte Carlo approximation. Monte Carlo simulation calculated the last year of the decadal subsample sequence for sample L1-k3 at $1847 \mathrm{cal} \mathrm{BC}, \chi^{2}=6.6$ at $p=15.8 \%$; 1750 cal BC for sample L4-k1, $\chi^{2}=0.4$ at $p=99.6 \% ; 1744$ cal BC for sample L4-K6, $\chi^{2}=1.9$ at $p=$ 99.9\%; and 1744 cal BC for sample L5, $\chi^{2}=0$ at $p=99.1 \%$. The suggested fit for sequence L4-k6 agrees well with the shape of the calibration curve but generates a larger number of offsets ( 7 offsets out of 11 points). However, sliding the sequence L4-k6 until it was closer to the calibration curve brings its end to 1660 cal BC, accurately following the calibration curve (Figure 2). In fact, this fit corresponds better to the averaged age of the decadal groups (Table 3). We advocate the true age of the L4-k6 is likely to be 1660 cal BC. The correlation obtained for the L1-k3 sequence was insignificant. The Monte Carlo simulation suggested a final year at $1850 \mathrm{cal} \mathrm{BC}$ for the 4-point sequence of L1-k3 with 3 large offsets, although a better fit might be found at 1800 cal BC. Consequently, 1800 cal BC was chosen to represent the true age of the sample from L1. The age of the 2-point sequence L4-k1 is $\sim 1700 \mathrm{BC}$. In both cases, 1 or more of ${ }^{14} \mathrm{C}$ values fall exactly on the calibration curve and the few offsets are closer to the curve. Thus, the visual match produced more densely clustered points on the calibration curve and better agreement between matching curves.

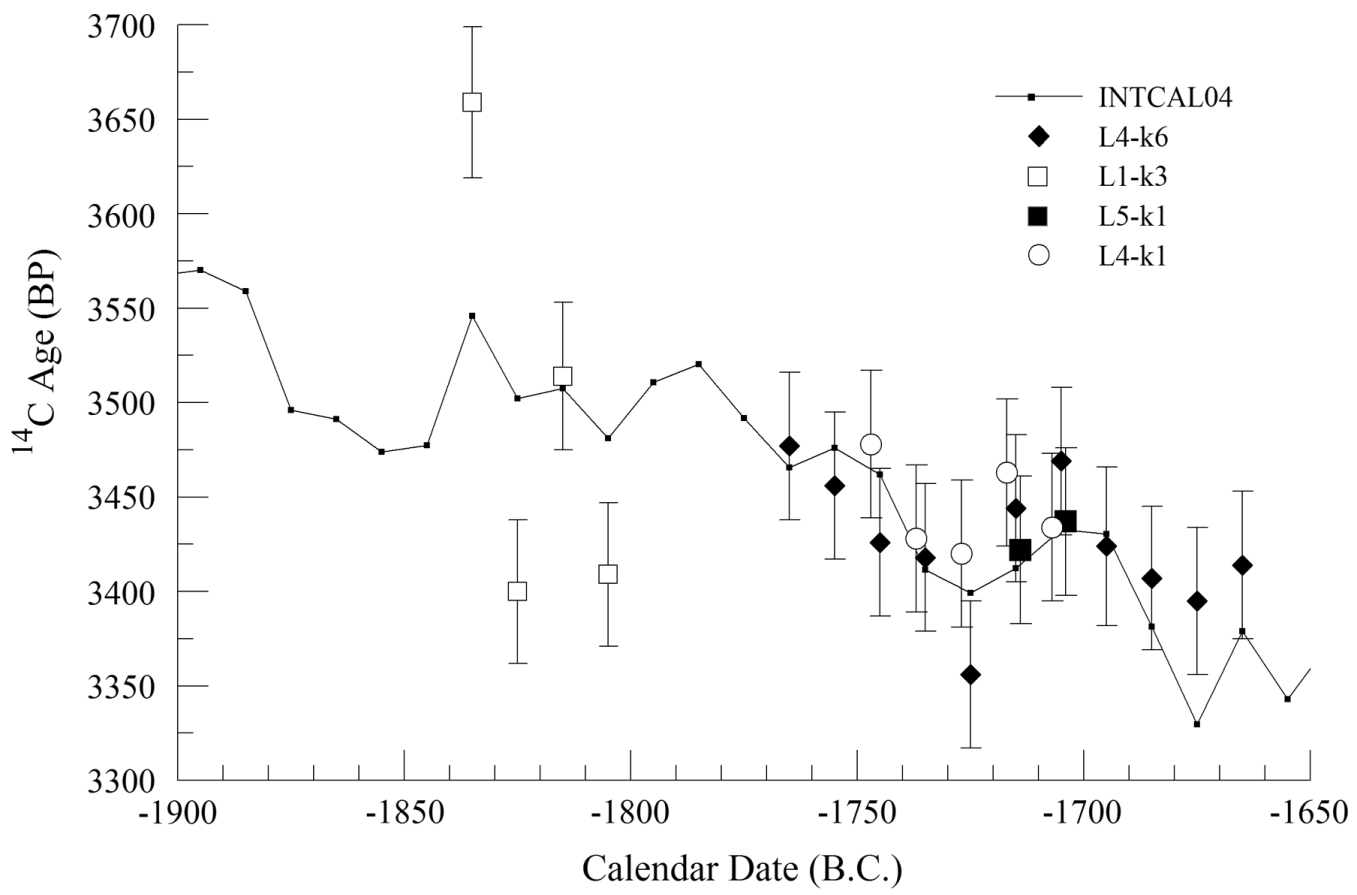

Figure 2 High-resolution ${ }^{14} \mathrm{C}$ calibration for tree-ring pine chronologies from the Lisakovsky site. The plot shows the best fits of ${ }^{14} \mathrm{C}$ sequences from the tree rings with the IntCal04 calibration curve (Reimer et al.2004).

The Monte Carlo simulation did not provide an unambiguous diagnosis of the age relationships. Nevertheless, the comparison of different calibrating methods finds the best possible agreement with the calibration curve and determines reasonable calendar ages for the Andronovo cemeteries. 
Table 3 Calendar age of the Lisakovsky complex derived from wiggle matching and averaging replicated ${ }^{14} \mathrm{C}$ ages (marked in bold).

\begin{tabular}{|c|c|c|c|c|c|}
\hline Cemetery \# & $\begin{array}{l}{ }^{14} \mathrm{C} \text { wiggle calibrated } \\
\text { age: visual fit vs. Monte } \\
\text { Carlo fit, end year (BC) }\end{array}$ & $\begin{array}{l}\text { Averaged } \\
{ }^{14} \mathrm{C} \text { age } \\
\pm 1 \sigma(\mathrm{BP})\end{array}$ & $\begin{array}{l}\text { Calibrated averaged } \\
{ }^{14} \mathrm{C} \text { age } \pm 1-\sigma \text { ranges } \\
\text { and their probability } \\
\text { distribution }(\mathrm{BC})\end{array}$ & $\begin{array}{l}\text { Excepted } \\
\text { calendar } \\
\text { age of } \\
\text { cemetery } \\
\text { (cal BC) }\end{array}$ & $\begin{array}{l}\text { Total \# of } \\
\text { burials per } \\
\text { cemetery }\end{array}$ \\
\hline $\begin{array}{l}\text { L1 } \\
\text { L1-K3 }\end{array}$ & 1800 / 1850 & $3496 \pm 40$ & $\begin{array}{ll}1880-1860 & 0.21 \\
\mathbf{1 8 6 0}-\mathbf{1 7 7 0} & \mathbf{0 . 7 9}\end{array}$ & $1780^{\mathrm{a}}$ & 174 \\
\hline $\begin{array}{l}\text { L4 } \\
\text { L4-K1 }\end{array}$ & $1700 / 1750$ & $3445 \pm 40$ & $\begin{array}{ll}1870-1840 & 0.20 \\
1810-1800 & 0.06 \\
\mathbf{1 7 8 0}-1730 & \mathbf{0 . 4 6}\end{array}$ & $1670^{\mathrm{a}}$ & 18 \\
\hline L4-K6 & $1660 / 1744$ & $3427 \pm 40$ & $\begin{array}{ll}1720-1690 & 0.28 \\
1870-1850 & 0.11 \\
\mathbf{1 7 7 0}-\mathbf{1 6 8 0} & \mathbf{0 . 8 9}\end{array}$ & 1660 & \\
\hline L4-SR9 ${ }^{b}$ & $\mathrm{n} / \mathrm{a}$ & $3457 \pm 40$ & $\begin{array}{ll}1870-1840 & 0.28 \\
1820-1800 & 0.16 \\
\mathbf{1 7 8 0}-\mathbf{1 7 4 0} & \mathbf{0 . 4 2} \\
1710-1690 & 0.13\end{array}$ & $1780-1740$ & \\
\hline $\begin{array}{l}\text { L5 } \\
\text { L5-K1 }\end{array}$ & $1740 / 1744$ & $3430 \pm 40$ & $\begin{array}{ll}1870-1850 & 0.12 \\
\mathbf{1 7 7 0}-1680 & \mathbf{0 . 8 8}\end{array}$ & 1740 & 3 \\
\hline
\end{tabular}

aEnd year adjusted with crossdates.

${ }^{b}$ Date derived from a single measurement.

The wiggle matching increased the precision of calibrated ages up to $10 \mathrm{yr}$ for specimens L4-k1, L4$\mathrm{k} 6$, and L5. These results demonstrate that replicating ${ }^{14} \mathrm{C}$ measurements from crossdated tree rings made in a single AMS laboratory employing a single wood pretreatment method significantly reduces the error of true ages and eliminates randomly occurring small errors as was found in other related studies (Scott et al. 2007; Panyushkina et al. 2007).

\section{Age of Cemeteries at the Lisakovsky Complex}

The calibrated ${ }^{14} \mathrm{C}$ dates were adjusted by adding a number of missing tree rings estimated from mean tree-ring widths and the diameter of archaeological timbers (Tables 1, 3). The tree-ring adjustment brought the ${ }^{14} \mathrm{C}$ wiggle date from the earliest burial at Lisakovsky 1 closer to dates from other burial fields in the Lisakovsky complex. According to the adjustment, the earliest constructed burials at Lisakovsky 1 were dated to $\sim 1760 \mathrm{BC}$, which is just $20 \mathrm{yr}$ from the Lisakovsky 5 date $(\sim 1740$ $\mathrm{BC}$ ). The Lisakovsky 4 enclosure (SR9) surrounding 3 graves at the cemetery was dated to about 1780-1740 BC. This burial group is separated from the other assemblages at Lisakovsky 4. Two kurgans from the largest assemblage of the cemetery were erected much later at about 1670 and 1660 BC. Three features, out of the 18 burials at Lisakovsky 4, showed a 120-yr period of burial construction. Taking into consideration the greater number of burials preserved at Lisakovsky 1 in particular, we believe that the growth of cemetery 1 falls in the same period as cemetery 4 (Table 3 ).

This suggests that all 3 studied cemeteries were used between about 1780 and $1660 \mathrm{BC}$. The cemeteries were contemporaneous over the course of a few generations of the Andronovo people inhabiting this particular complex of sites along the upper Tobol River. The age of the Lisakovsky site appears to be a few centuries older than was previously thought based on formal attribution to the Lisakovsky ceramics (1500-1400 BC, Usmanova 2005). Remarkably, the ${ }^{14} \mathrm{C}$ dates of this site are consistent with the main wave of Andronovo colonization of the Eurasian steppe during the transi- 
tion between the Middle and Late Bronze Ages. The chronological order of dated burials reveals the arrival of the Andronovo population into this region by at least $\sim 1780 \mathrm{BC}$ and establishes the southern boundary of rapid dispersal of the Andronovo into the steppe.

\section{Age of Alakul and Fedorovo Cultures}

As mentioned, the relationship between the Alakul and Fedorovo cultures is the key question in Andronovo archaeology, driven by the great conflict between the linguistic and ethnographic arguments. The new dates from the Lisakovsky multiphased site bring new insights into the origins of different groups in the Urals region. The Lisakovsky dates were derived from the Alakul culture occurrences as the majority of site assemblages. The number of exclusively Fedorovo occurrences is fewer at the same cemeteries, in contrast to the greater amounts of mixed Alakul-Fedorovo assemblages (Usmanova 2005). While the evidence of contemporaneous cemeteries related to both Alakul and Fedorovo cultures overlaps these traditions in the southern Urals as early as $\sim 1780 \mathrm{BC},{ }^{14} \mathrm{C}$ dates derived from the multiphased Urefty and Kamennaya Rechka sites at the northern boundary of the Ural steppe synchronize the Alakul and Fedorovo traditions from 1880 to 1600 BC (Hanks et al. 2007). This indicates that the grouping of Fedorovo and Alakul cultures may have occurred in the southern steppe almost $100 \mathrm{yr}$ later than in the northern steppe.

Further comparison of our dates to the currently most reliable set of ${ }^{14} \mathrm{C}$ dates in the region published by Hanks et al. (2007) shows the Fedorovo presence in the northern steppe until 1690 cal BC. However, Fedorovo people remained residing in the southern steppe region until at least $1660 \mathrm{BC}$ according this study. This indicates the extended overlap of the Fedorovo and Alakul cultures in the south and possible migration of the Fedorovka-Alakul alliance toward the south from the north. This observation supports Salnikov's (1967) approach to the Andronovo phenomena, which credits migration of the Ugrian people from the forested north and development of the Fedorovo traditions through contact with steppe people. Furthermore, the developed chronology seriously challenges the hypothesis attributing the homeland of the Fedorovo culture to the southernmost margin of the Eurasian steppe (central Kazakhstan or even Iran) and the Fedorovo's movement into the northern Alakul territory during the Late Bronze Age (Kuzmina 1994; Grigoriev 2002).

\section{CONCLUSION}

Andronovo timbers are a reliable and precious resource for obtaining calendar dates via highly resolved ${ }^{14} \mathrm{C}$ wiggles from the Bronze Age occurrences in the Eurasian steppe. The ${ }^{14} \mathrm{C}$ wiggles from the Lisakovsky timbers determine the development of cemeteries at the Lisakovsky site cluster over a 120-yr period from about 1780-1660 BC. The calendar dates place the Alakul in the Tobol River valley at the transition from the Middle to Late Bronze Age. The chronological order of cemeteries establishes contemporaneity of the Alakul and Fedorovo traditions at the site. The duration of the Fedorovo, Alakul, and their mixed variant within the southern border of the Andonovo distribution in the Urals suggests the Fedorovo tradition must have been present in the region by at least $1780 \mathrm{BC}$ as well. This chronological evidence substantiates the compelling need for highly resolved ${ }^{14} \mathrm{C}$ dates that can be developed from Bronze Age archaeological timbers across Eurasia. These findings will simplify interpretation of cultural relationships between various ethnic groups inhabiting the Eurasian steppe and clarify their economic and social dimensions, and possibly even linguistic relations. 


\section{ACKNOWLEDGMENTS}

This study was supported by the National Geographic Society (award \#8244-07). We thank the University of Arizona NSF AMS Facility for prompt dating of the samples. We are extremely grateful to the Museum of History and Culture of Upper Tobol region (especially N Jilyaeva and A Suslov) for providing access to the collections, and S Shiyatov and V Mazepa for kindly sharing tree-ring facilities at DendroLab of RAS Institute of Animal and Plant Ecology (Russia), and L Agafonov for wood anatomy identification of our specimens.

\section{REFERENCES}

Anthony DW. 2007. The Horse, the Wheel, and Language: How Bronze-Age Riders from the Eurasian Steppes Shaped the Modern World. Princeton: Princeton University Press. 566 p.

Bronk Ramsey C, van der Plicht J, Weninger B. 2001. 'Wiggle matching' radiocarbon dates. Radiocarbon 43(2A):381-9.

Frachetti MD. 2004. Bronze Age pastoral landscapes of Eurasia and the nature of social interaction in the mountain steppe zone of eastern Kazakhstan [PhD dissertation]. Philadelphia: University of Pennsylvania.

Gening VF, Zdanovich GB, Gening VV. 1992. Sintashna-1: arkheologicheske pamyatniki ariyskikh plemen Uralo-Kazakhskikh stepey [Sintashta I: archaeological sites of Aryan tribes in the Ural-Kazakh steppe]. Chelyabinsk: Yujno-Uralskoe Publishing House. In Russian.

Gorsdorf J, Parzinger H, Nagler A. 2004. ${ }^{14} \mathrm{C}$ dating of the Siberian steppe zone from Bronze Age to Scythian time. In: Scott EM, Alekseev AY, Zaitseva GI, editors. Impact of the Environment on Human Migration in Eurasia. NATO Science Series IV. Dordrecht: Kluwer Academic Publishers. p 83-90.

Grigoriev SA. 2002. The Sintashta culture and Indo-European problem. In: Jones-Bley K, Zdanovich D, editors. Complex Societies of Central Eurasia from the 3rd to the 1st Millennium BC: Regional Specifics in Light of Global Models. Journal of Indo-European Studies Monograph Series 45. Washington, D.C.: Institute for Study of Man. p 148-60.

Hanks BK, Epimakhov AV, Renfrew AC. 2007. Towards a refined chronology for the Bronze Age of the southern Urals, Russia. Antiquity 81(312):353-67.

Koryakova LN, Epimakhov AV. 2007. The Urals and Western Siberia in the Bronze and Iron Ages. New York: Cambridge University Press. 383 p.

Kuzmina E. 1994. Otkuda prishli Indoaryi? Materialnaia kultura plemen andronovskoi obshchnosti $i$ proiskhozhdenie indoirantsev [Whence came the Indo Aryans]. Moscow: Vostochnaia literatura. In Russian.

Lange T, Barbetti M, Donahue DJ. 2001. Radiocarbon measurements of tree rings from $14 \mathrm{ka}$ Huon pine. $R a$ diocarbon 43(2A):449-52.

Panyushkina IP, Sljusarenko IY, Bikov N, Bogdanov E. 2007. Floating larch tree-ring chronologies from archaeological timbers in the Russian Altai between about 800 BC and AD 800. Radiocarbon 49(2):693-
702.

Potemkina TM. 1985. Bronzoviy vek leso-stepnogo Protobolya [Bronze Age of forest-steppe Pritobolye]. Moscow: Nauka. In Russian.

Reimer PJ, Baillie MGL, Bard E, Bayliss A, Beck JW, Bertrand CJH, Blackwell PG, Buck CE, Burr GS, Cutler KB, Damon PE, Edwards RL, Fairbanks RG, Friedrich M, Guilderson TP, Hogg AG, Hughen KA, Kromer B, McCormac G, Manning S, Bronk Ramsey C, Reimer RW, Remmele S, Southon JR, Stuiver M, Talamo S, Taylor FW, van der Plicht J, Weyhenmeyer CE. 2004. IntCal04 terrestrial radiocarbon age calibration, 0-26 cal kyr BP. Radiocarbon 46(3):1029-58.

Rinn F. 2003. Time Series Analysis and Presentation software (TSAP-Win). User Reference (Version 0.53). RinnTech, Heidelberg, Germany.

Salnikov KV. 1967. Ocherki drevney istorii Yuzhnogo Urala [Ancient history of the southern Urals]. Moscow: Nauka. In Russian.

Scott EM, Cook GT, Naysmith P. 2007. Error and uncertainty in radiocarbon measurements. Radiocarbon 49(2):427-40.

Shishlina NI, van der Plicht J, Hedges REM, Zazovskaya EP, Sevastyanov VS, Chichagova OA. 2007. The catacomb cultures of the north-west Caspian steppe: ${ }^{14} \mathrm{C}$ chronology, reservoir effect, and paleodiet. Radiocarbon 49(2):713-26.

Stefanov VI, Korochkova ON. 2006. Urefty-I. Ekaterinburg: Ural State University Press. In Russian.

Sternberg LSL. 1989. Oxygen and hydrogen isotope measurements in plant cellulose analysis. In: Linskens HF, Jackson JF, editors. Plant Fibers. Modern Methods of Plant Analysis. Volume 10. New York: Springer-Verlag. p 89-99.

Stuiver M, Reimer PJ, Reimer RW. 2005. CALIB radiocarbon calibration [software]. URL: http:// calib.qub.ac.uk/calib/.

Usmanova ER. 2005. Mogil'nik Lesakovskiy: fakti i paralleli [Burial complex Lisakovsky: facts and parallels]. Karaganda: Lisakovsk. In Russian.

Weninger B. 1997. Monte Carlo wiggle matching. Zur statistischen auswertung der mittelneolithischen 14Cdaten von Hasselsweiler 2, Inden 3, and Inden 1. In: Biermann E, editor. Großgartach und Oberlauterbach. Interregionale Beziehungen im süddeutschen Mittelneolithikum. Archäologische Berichte 8:91-113. 